\title{
A Review of the Association of Petroliferous Materials with Uranium and Other Metal Deposits in Sedimentary Rocks in the United States
}

\section{U.S. GEOLOGICAL SURVEY BULLETIN 1798}





\section{A Review of the Association of Petroliferous Materials with Uranium and Other Metal Deposits in Sedimentary Rocks in the United States}

\section{By LEONARD J. SCHMITT}

A survey of stratabound uranium and other metal deposits in the United States to determine if there is evidence that petroleum-derived materials are associated 


\title{
DEPARTMENT OF THE INTERIOR \\ DONALD PAUL HODEL, Secretary
}

\author{
U.S. GEOLOGICAL SURVEY \\ Dallas L. Peck, Director
}

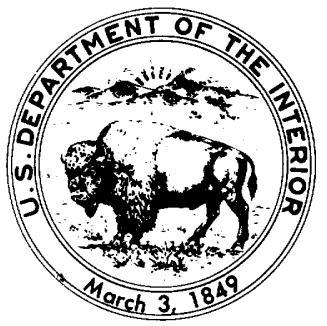

UNITED STATES GOVERNMENT PRINTING OFFICE, WASHINGTON: 1988

For sale by the

Books and Open-File Reports Section

U.S. Geological Survey

Federal Center

Box 25425

Denver, CO 80225

Library of Congress Cataloging-in-Publication Data

Schmitt, Leonard J.

A review of the association of petroliferous materials with uranium and other metal deposits in sedimentary rocks in the United States.

(U.S. Geological Survey bulletin ; 1798)

Bibliography: $p$.

Supt. of Docs. no.: I 19.3:1798

1. Petroleum-Geology-United States. 2. Uranium-United States. 3. Rocks, Sedimentary. I. Title. II. Series.

QE75.B9 no. 1798

[TN872.A5]

$557.3 \mathrm{~s}$

[553.2' 82]

87-600267 


\title{
CONTENTS
}

\author{
Abstract 1 \\ Introduction 1 \\ Previous investigations 2 \\ Present investigation 3 \\ Acknowledgments 3
}

Geology of uranium districts or deposits that show positive associations with petroliferous materials 3

Cement, Oklahoma 3

Elk Ridge, Utah 5

Lance Creek, Wyoming 5

Lone Tree deposit, San Rafael Swell, Utah 5

Maybell, Colorado 5

Palangana salt dome, Texas 5

Poison Basin, Wyoming 5

South Texas 6

Temple Mountain, Utah 6

Deposits in the Todilto Limestone Member of the Wanakah Formation of the Grants area, New Mexico 6

Geology of uranium occurrences that show positive associations with petroliferous materials 7

Carlsbad, New Mexico 7

Chalone Creek, California 7

Edna, California 7

Ellis, Missouri 7

Huntsville, Arkansas 7

Los Alamos, California 7

McKittrick, California 7

Southwestern Oklahoma 8

Sulphur, Oklahoma 8

Vernal, Utah 8

Geology of uranium districts that may show positive associations with petroliferous materials 8

Copper Mountain, Wyoming 8

Crooks Gap, Wyoming 8

Gas Hills, Wyoming 8

Lisbon Valley, Utah 9

Deposits in the Morrison Formation of the Grants area, New Mexico 9

Rifle Creek, Colorado 9

Shirley Basin, Wyoming 10

White Canyon, Utah 10 
Geology of uranium districts or mines that apparently show no positive associations with petroliferous materials 10

Anderson mine, Date Creek Basin, Arizona 10

Cameron, Arizona 10

Edgemont, South Dakota 11

Highland deposit, Powder River Basin, Wyoming 11

Mauch Chunk, Pennsylvania 11

Monument Hill, Powder River Basin, Wyoming 11

Monument Valley, Arizona 11

Orphan mine, Grand Canyon, Arizona 12

Tallahassee Creek, Colorado 12

Uravan mineral belt, Colorado 12

Geology of metalliferous districts other than uranium that show positive associations with petroliferous materials 12

Lake Alice $\mathrm{Cu}-\mathrm{Ag}-\mathrm{Zn}$ district, Wyoming 12

Picher-Miami field of Tri-State Pb-Zn district, Oklahoma-Kansas 12

Upper Mississippi Valley $\mathrm{Pb}-\mathrm{Zn}$ district, southwestern Wisconsin and adjoining States 13

Geology of metalliferous districts other than uranium that may show positive associations with petroliferous materials 13

Bent (Virginia) red-bed(?) Cu deposit, New Mexico 13

Fredericktown $\mathrm{Pb}$ district, Missouri 13

Silver Reef district, Utah 13

Geology of metalliferous districts other than uranium that probably do not show positive associations with petroliferous materials 13

Guadalupe (Stauber) red-bed Cu deposit, New Mexico 13

Pintada Lode red-bed $\mathrm{Cu}$ deposits, New Mexico 13

Sierra Nacimiento $\mathrm{Cu}$ deposits, New Mexico 14

Discussion 14

Conclusions 14

References cited 15

FIGURE

1. Index map of mineralized localities in the conterminous United States 4 


\title{
A Review of the Association of Petroliferous Materials with Uranium and Other Metal Deposits in Sedimentary Rocks in the United States
}

\author{
By Leonard J. Schmitt
}

\begin{abstract}
The role that petroliferous materials played in the localization of uranium and other metal deposits in sediments was assessed. Some of the ways in which petroliferous materials may be related to metal deposits in sediments are as follows: (a) hydrogen sulfide from oil or gas fields could have migrated up faults and fractures and precipitated metals in local traps; (b) petroliferous material, such as asphalt, could have precipitated metals directly; (c) petroleum may have acted as an ore-forming fluid; and, (d) oil field brines may have acted as ore-forming fluids.

Uraniferous asphaltite is an enigmatic substance whose origin has been related to both coal and petroleum. Thucholite, a presumably related substance, contains both thorium and uranium but is generally not found in sedimentary rocks. However, both uraniferous asphaltite and thucholite have been subjected to radiation that has altered the materials from their original state, which makes their identity and genetic study difficult.

At the Palangana salt dome in Texas, uranium and oil occur in the basal part of the Pliocene Goliad Sand overlying the caprock of the salt dome. In the south Texas district, uranium deposits show close spatial relations to fault-line oil fields; the buried Edwards Limestone of Early Cretaceous age contains significant amounts of hydrogen sulfide, a potential precipitant for uranium. In the Temple Mountain uranium district, Utah, the association of oil or asphalt with uraniferous asphaltite over a wide stratigraphic interval suggests a genetic relation. At Carlsbad, New Mexico, uraniferous asphaltite nodules and patches of residual oil occur in back-reef dolomites of Late Permian age. On the basis of carbon isotope data and geologic field relations, an oil-related origin has been proposed for the uraniferous carbonaceous nodules of southwestern Oklahoma. Natural gas seeps and pockets encountered in drilling, some containing hydrogen sulfide, occur in the Gas Hills uranium district, Wyoming. In the deposits in the Morrison Formation of the Grants uranium area, New Mexico, a dark-colored carbonaceous substance is generally coextensive with primary
\end{abstract}

uranium ore, and the origin of the substance has been attributed to both asphalt and humic acid. In the Lisbon Valley uranium district, Utah, remote sensing of bleaching in the Upper Triassic Wingate Sandstone has demonstrated a close spatial relation with underlying uranium deposits in the Upper Triassic Chinle Formation as well as with oil and gas structures. Petroliferous material has been reported from some mines in the district.

After considering a number of uranium deposits, I conclude that uranium cannot be used to predict the occurrence of petroleum, and the occurrence of oil and gas cannot be used to predict the occurrence of uranium, although uranium and petroleum do tend to occur together in nature. Organic matter, whether petroliferous or coaly, does show a marked positive correlation with uranium.

\section{INTRODUCTION}

A positive relation between carbonaceous material and both uranium and other metal deposits in sedimentary rocks has been well established, but the relation between petroliferous materials and both uranium and other metal deposits was heretofore uncertain. In part, this uncertainty exists because some hydrocarbons are extremely difficult to identify by conventional analysis. In addition, oil and gas fields commonly occur close to some metal deposits, but a genetic connection is difficult to establish.

Petroliferous materials could form metal deposits in sediments in four ways. One way is for hydrogen sulfide from oil or gas pools to migrate along faults and fractures and precipitate metals in local traps. Hydrogen sulfide is an effective reducing agent that can precipitate uranium, copper, lead, zinc, and other metals from aqueous solutions. Hydrogen could probably substitute for hydrogen sulfide but it is generally not as abundant. Recognizing hydrogen sulfide as coming from oil or gas 
fields as opposed to other sources presents some difficulty. Asphalt is a petroliferous material that can precipitate uranium and other metals. Some asphalts contain uranium and other metals in considerably greater amounts than most petroleums (Erickson and others, 1954; Bell, 1960). Uraniferous asphaltite, common in the San Rafael Swell area of Utah, is either an indurated hydrocarbon, indurated perhaps as a result of radiation, or a hardened derivative of coal, perhaps originally a humic acid. The evidence is inconclusive. A third way involves petroleum acting as an ore-forming fluid. The uranium content of most petroleums is so low that it is most unlikely that petroleum could form uranium ore deposits; yet other metals, such as vanadium and nickel, occur in sufficient quantities in some petroleums that ore formation cannot be ruled out. Finally, a fourth way of forming metal deposits is with oil field brines. Oil field brines have been suggested as ore-forming solutions in some Mississippi Valley-type lead-zinc deposits (Sverjensky, 1984).

\section{Previous Investigations}

Russell (1958) was one of the first to report a general relation between uranium ore deposits and petroleum- and gas-bearing structures. He briefly described several uranium districts and deposits in the United States in which petroliferous materials are conspicuously present. Grutt (1957) reported the occurrence of natural gases containing hydrogen sulfide in certain uranium districts of Wyoming and northern Colorado, especially in the Gas Hills district, Wyoming. He believed that the hydrogen sulfide was responsible for the precipitation of iron disulfide and reduction of uranium. Birdseye (1957) described the relation of the Ambrosia Lake, N. Mex., uranium deposits to a preexisting oil pool. He believed that the organic material intimately mixed with the uranium ore was a petroliferous residue resulting from the migration of oil away from the Ambrosia Lake dome. Zitting and others (1957) stated that the organic material was a humic acid that was thought to have formed by oxidation of an asphalt accumulation.

Bain (1906) studied the lead-zinc deposits of the upper Mississippi Valley district and concluded that petroliferous material from a stratum known locally as the "oil rock" caused the precipitation of the metals by reduction, either directly or indirectly through the formation of hydrogen sulfide. Hess (1922) investigated the uraniferous asphaltites located at Temple Mountain, Utah, and adjacent areas and suggested that asphaltite may react toward uranium in a way similar to other carbonaceous material. He further suggested that the hardened nature of the asphaltite might be caused by the contained metals. Fowler (1933) pointed out the occurrence of liquid petroleum in some lead-zinc mines of the Picher-Miami field of the Tri-State mining district. As the water table was lowered locally in the mines, oil from overlying rock units entered the mine workings. Whether the association of oil and ore is fortuitous or if a genetic connection exists is unclear in this instance.

Thucholite, a radioactive mineraloid so named because it contains thorium, uranium, carbon, hydrogen, and oxygen, was first described from a pegmatite dike in the Parry Sound district of Ontario by Ellsworth (1928). Although this report is concerned with metalliferous deposits in sedimentary rocks, mention of thucholite is appropriate because of its similarity to uraniferous asphaltite. Spence (1930) described thucholite from another pegmatite locality, the Besner mine, in the Parry Sound district, and theorized that the material formed by radiation from uraninite acting on oil present in the pegmatite. Davidson and Bowie (1951) investigated thucholite and related radioactive hydrocarbons from several localities and concluded that these materials were formed by alpha radiation of methane and other gaseous hydrocarbons. Barthauer and others (1953) made a nearly complete analysis of thucholite from the Besner mine, Parry Sound district, Ontario, and found that the thorium content was the lowest reported up to that time, suggesting that the composition of thucholite varies widely. Hoekstra and Fuchs (1960) also investigated thucholite from the Besner mine, Parry Sound district, Ontario, and concluded that it was formed by the action of aqueous solutions containing organic material, possibly as an oilwater emulsion.

Gruner (1955) proposed that asphaltite is derived from plant material, largely on the basis of the nearly universal association of uranium and fossil plant material in sediments. Davidson (1955) disagreed with this view and observed that in a single hand specimen may be seen a woody hydrocarbon predating pitchblende and a thucholite hydrocarbon or asphaltite postdating pitchblende. Breger (1955) concluded that asphaltite and related substances were derived from coalified wood. Kerr and Kelley (1956, p. 389) believed that the urano-organic ores at Temple Mountain in the San Rafael Swell, Utah, originated from petroliferous material that was "indurated under hydrothermal conditions."

Hail (1957) found significant amounts of uranium in the ash of oil extracted from asphalt-bearing rocks in samples from 7 of 45 areas examined in California, Utah, Wyoming, Montana, New Mexico, Texas, Oklahoma, and Missouri. Hill (1957) found that spectrographic analyses of uranium-bearing carbonaceous nodules occurring along the north flank of the Wichita uplift in southwestern Oklahoma showed an assemblage of trace metals similar to that found in nearby crude oils. Sims (1957) found that Wyoming crude oil is capable of extracting uranium from aqueous, acidic solutions by 
solvent extraction. Pierce and others (1958) concluded that the uraniferous carbonaceous mineraloids formed from substances associated with petroleum and that their original structure and composition were altered because of radiation. Breger and Deul (1959) concluded from their studies that on the Colorado Plateau uranium is associated with coalified wood and related substances, not with petroliferous materials.

Hausen (1959) stated that much of the asphaltite from Temple Mountain, Utah, was probably derived from petroleum, which was polymerized in place by radiation from uranium and its daughter products. Bell (1960) stated that no evidence exists to support the origin of some uranium deposits by deposition by petroliferous fluids. He further pointed out that uraniferous asphaltites cannot definitely be classified as petroleum derivatives. Eargle and Weeks (1961) suggested that hydrogen sulfide from fault-controlled oil fields may have precipitated uranium in nearby sedimentary rocks and formed the uranium deposits of south Texas. Germanov (1961) related epigenetic uranium mineralization, such as at the Ambrosia Lake, N. Mex., deposit, to processes occurring in the marginal parts of petroliferous artesian basins. Hyden (1961) found that crude oil can leach uranium from sandstone containing uranium minerals such as uraninite and carnotite. Pierce and others (1964) reported that uraniferous asphaltite, probably petroleum derived, occurs in the cap rock of the Panhandle gas field, Texas, and is the source of an abnormally high radon concentration in gases from a number of wells. Hawley and others (1965) studied the uranium deposits of the Temple Mountain district, Utah, and concluded that the uraniferous asphaltites were derived from petroleum.

Haji-Vassiliou and Kerr (1973) studied the uranoorganic materials from several uranium deposits by infrared spectroscopy and organic elemental analysis and concluded that decayed vegetation provides the main source of the organic matter in all the major uranoorganic deposits. Eargle and others (1975) stated that the reducing agents for uranium in the south Texas deposits were probably local carbonaceous material and hydrogen sulfide or methane that originated in nearby buried petroleum accumulations. Handford and Granata (1979) studied the uraniferous asphaltite from the cap rock of the Panhandle gas field, Texas, and agreed with Pierce and others (1964) that the asphaltite was derived from petroleum. Busche and others (1981) reported on the sulfur isotopic compositions of iron disulfide minerals associated with some south Texas uranium deposits and determined that the ore-stage iron disulfide did not form from faultleaked sour gas. The ore-stage iron disulfide contains isotopically light sulfur, whereas the sour gas contains isotopically heavy sulfur. Curiale and others (1983) studied uraniferous organic-rich nodules from southwestern Oklahoma and concluded that their infrared spectra and elemental analyses have characteristics of both coal and petroleum. They further concluded that carbon isotopic data and geologic field relations suggest a relation to oil rather than coal.

Clearly, a review of the literature shows that the subject is controversial and not amenable to simple solution. However, regardless of which origin is favored, organic carbon played an important role in the formation of uranium deposits in sedimentary rocks.

\section{Present Investigation}

In the present study, no new field or laboratory data have been generated. The investigation is limited to a critical review of the literature and discussions with geologists of the U.S. Geological Survey who are knowledgeable about specific deposits or districts. Each deposit or district was categorized into one of three groups: (1) deposits or districts that show positive associations with petroliferous materials; (2) deposits or districts that may show positive associations; and (3) deposits or districts that apparently show no positive associations.

The choice of which districts or deposits to include in this study was selective. However, most of the important sandstone-type uranium deposits are included. The mineralized localities are shown on a map of the conterminous United States in figure 1.

\section{Acknowledgments}

For their aid and assistance in this study thanks are due C. G. Bowles, K. A. Dickinson, W. I. Finch, H. C. Granger, P. L. Hansley, A. R. Kirk, J. S. Leventhal, J. K. Otton, J. F. Robertson, E. S. Santos, and R. E. Thaden, all of the U.S. Geological Survey.

\section{GEOLOGY OF URANIUM DISTRICTS OR DEPOSITS THAT SHOW POSITIVE ASSOCIATIONS WITH PETROLIFEROUS MATERIALS}

\section{Cement, Oklahoma}

At Cement in southwestern Oklahoma, a small amount of joint-controlled uranium ore has been mined from the crest of an oil-producing anticline (Russell, 1958) (fig. 1, no. 38). Sandstones of the Upper Permian Rush Springs Formation are hosts for the ore and are variably bleached in the vicinity of mineralization (Allen and Thomas, 1984), with bleaching of the normally red colored sandstone related to hydrocarbon microseepage (Donovan, 1974). The close spatial relation between uranium, faults and fractures, and oil and gas suggests a genetic connection. 


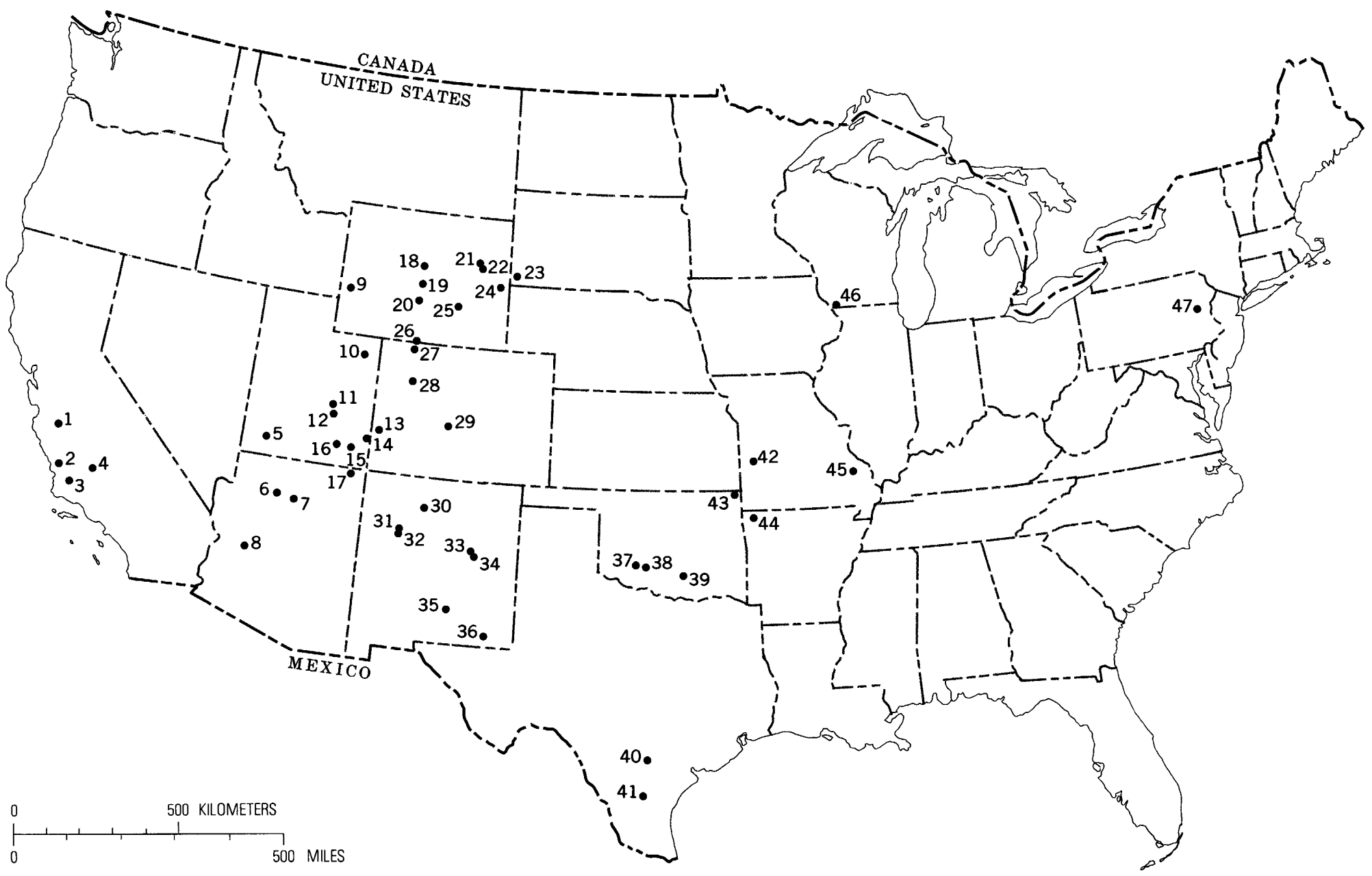

Figure 1. Index map of mineralized localities in the conterminous United States.

1. Chalone Creek, Calif. (U)

2. Edna, Calif. (U)

3. Los Alamos, Calif. (U)

4. McKittrick, Calif. (U)

5. Silver Reef, Utah (Ag)

6. Orphan mine, Grand Canyon, Ariz. (U)

7. Cameron, Ariz. (U)

8. Anderson mine, Date Creek Basin, Ariz. (U)

9. Lake Alice, Wyo. (Cu-Ag-Zn)

10. Vernal, Utah (U)

11. Lone Tree deposit, San Rafael Swell, Utah (U)

12. Temple Mountain, Utah (U)

13. Uravan mineral belt, Colorado (U)

14. Lisbon Valley, Utah (U)

15. Elk Ridge, Utah (U)

6. White Canyon, Utah (U)

17. Monument Valley, Ariz. (U)
Copper Mountain, Wyo. (U)

Gas Hills, Wyo. (U)

Crooks Gap,

Monument Hill, Powder River Basin, Wyo. (U)

Highland deposit, Powder River Basin, Wyo. (U)

Edgemont, S. Dak. (U)

Lance Creek, Wyo. (U)

Shirley Basin, Wyo. (U)

Poison Basin, Wyo. (U)

Maybell, Colo. (U)

Tallahassee Creek, Colo. (U)

Sierra Nacimiento deposits,

Uranium deposits in the Morrison Formation of the Grants

area, N. Mex. (U)

Uranium deposits in the Todilto Limestone Member of the

Wanakah Formation of the Grants area, New Mexico (U)
33. Pintada Lode red-bed deposits, N. Mex. (Cu)

34. Guadalupe (Stauber) red-bed deposit, N. Mex. (Cu)

35. Bent (Virginia) red-bed(?) deposit, N. Mex. (Cu)

36. Carlsbad, N. Mex. (U)

37. Southwestern Oklahoma (U)

38. Cement, Okla. (U)

39. Sulphur, Okla. (U)

40. South Texas (U)

41. Palangana salt dome, Texas (U)

42. Ellis, Mo. (U)

43. Picher-Miami field of Tri-State district, Oklahoma-

Kansas (Pb-Zn)

44. Huntsville, Ark. (U)

45. Fredericktown, Mo. $(\mathrm{Pb})$

46. Upper Mississippi Valley district, southwestern Wiscon-

sin and adjoining States $(\mathrm{Pb}-\mathrm{Zn})$ 


\section{Elk Ridge, Utah}

The Elk Ridge uranium area (fig. 1, no. 15) is located in the eastern part of the White Canyon uranium district (fig. 1, no. 16) in southeastern Utah in San Juan County. The Elk Ridge area is on the north end of the Monument upwarp, a broad, low, north-trending arch 48-65 km (30-40 mi) wide. The eastern side of the upwarp is bounded by the steeply dipping Comb monocline.

Uranium ore was produced almost exclusively from fluvial sandstone beds at the base of the Upper Triassic Chinle Formation where they fill shallow paleostream channels in the top of the Lower and Middle(?) Triassic Moenkopi Formation (Lewis and Campbell, 1965). An unconformity between the Chinle and Moenkopi may have served as a conduit for mineralizing solutions.

Carbonaceous material, interstitial blebs of asphaltite(?), and liquid hydrocarbons are locally abundant in the Chinle beds. Uranium-bearing asphaltite(?) is abundant in many mines and appears to be a major ore constituent (Lewis and Campbell, 1965). Uraninite, coffinite, uranophane, and tyuyamunite are the main ore minerals found in the area. Samples from which uraniferous asphaltite(?) has been mechanically concentrated invariably show uraninite $\mathrm{X}$-ray patterns (Lewis and Campbell, 1965).

The Elk Ridge area is similar in some respects to the Temple Mountain district in the San Rafael Swell, Utah (fig. 1, no. 12) in that organic materials of petroliferous origin occur with ore in both districts.

\section{Lance Creek, Wyoming}

The Lance Creek uranium occurrences are located on the flanks of the Lance Creek anticline in eastern Wyoming (fig. 1, no. 24). The Lance Creek anticline is an oil structure with multiple producing horizons. Uranium deposits in the area occur in and adjacent to fractures in conglomeratic sandstone lenses of the Oligocene White River Formation and in coal beds in the Paleocene Fort Union Formation (Bromley, 1955). The uranium minerals in the deposits are metatyuyamunite, uranophane, metazippeite, and schroeckingerite.

Fracturing and faulting have allowed hydrocarbons to migrate into favorable host sediments. The geologic setting at Lance Creek suggests an interaction between oil and gas and uranium.

\section{Lone Tree Deposit, San Rafael Swell, Utah}

The Lone Tree uranium deposit is located along the west side of the San Rafael Swell, Emery County, Utah (fig. 1, no. 11). The San Rafael Swell is a large, asymmetrical anticline about $160 \mathrm{~km}(100 \mathrm{mi})$ long and about
$80 \mathrm{~km}(50 \mathrm{mi})$ wide. The uranium deposits are in the basal part of the Upper Triassic Moss Back Member of the Chinle Formation.

The main ore zone is a brown, coarse sandstone

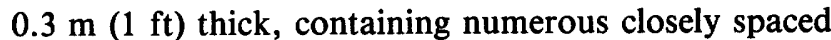
seams and blebs of uraniferous asphalt, overlying a $1.5 \mathrm{~mm}(1 / 16 \mathrm{in}$.) seam of pyrite (Reyner, 1950). Pellets of asphalt are widely scattered outside the main ore zone.

\section{Maybell, Colorado}

The Maybell uranium district is located in northwestern Colorado (fig. 1, no. 27) not far south of the Poison Basin uranium district in Wyoming (fig. 1, no. 26). The two districts do not differ greatly in geologic settings or in relations to petroliferous materials.

Uranium production in the Maybell district is from the gently dipping or horizontal Browns Park Formation of Miocene age located in an area of considerable highangle faulting (Grutt, 1957). Gas seeps, asphaltic materials, and asphaltite have been reported from within and near the district (Grutt, 1957; Russell, 1958; Sears, 1924). Asphaltic material occurs along some faults, suggesting that hydrocarbon migration was active in the area. Carbonaceous plant material is almost entirely absent.

\section{Palangana Salt Dome, Texas}

The Palangana salt dome, located on the coastal plain of southern Texas, contains one of the most unusual deposits of uranium (fig. 1, no. 41). The uranium occurs as uraninite, coating grains of sand in the basal part of the Pliocene Goliad Sand overlying the caprock of the salt dome. The basal Goliad is composed of highly calcareous clay-ball conglomerate interbedded with friable fine to medium sand locally impregnated with small amounts of oil (Weeks and Eargle, 1960).

A positive relation between petroliferous material and uranium deposits may be nowhere more evident than at the Palangana salt dome. Uranium ore formed where uraniferous solutions encountered pockets of hydrogen sulfide that originated in the caprock of the salt dome.

During 1928 and $1929,6,600$ barrels of oil were produced from the sands that form the uranium ore zone (Russell, 1958). The uranium deposit contains more than 0.9 million metric tons (1 million short tons) of ore.

\section{Poison Basin, Wyoming}

The Poison Basin uranium district is located in southern Wyoming near the town of Baggs (fig. 1, no. 26). The uranium deposits are in a small synclinal outlier of the Miocene Browns Park Formation that overlies an 
eroded anticline developed in the Paleocene and Eocene Wasatch Formation (Russell, 1958). The anticline, known as the South Baggs anticline, is a gas-bearing structure whose gases have permeated the Browns Park Formation along faults and permeable zones (Turner, 1955; Grutt, 1957). The Browns Park Formation is composed of fineto medium-grained gray and buff sandstones, tuffaceous sandstones, tuffs, and thin limestone beds. The source of the uranium was inferred as the tuffaceous material in the Browns Park Formation, and the uranium was probably precipitated by hydrogen sulfide as gas or dissolved in ground water (Grutt, 1957). Carbonaceous plant material is sparse or absent. Pyrite is abundant in the unoxidized zone.

\section{South Texas}

The south Texas uranium district is located on the coastal plain of south Texas (fig. 1, no. 40) and includes a number of widely scattered deposits. The ore deposits are of the roll type with large envelopes of altered rock and occur in tuffaceous, zeolitic sandstone and mudstone beds of the upper Eocene Whitsett Formation, the Oligocene(?) Frio Clay, and the Miocene Catahoula Tuff and Oakville Sandstone (Eargle and others, 1975). The beds strike northeastward and dip gently southeastward. The Catahoula Tuff is believed to be the principal source for uranium and other elements in the deposits. The uranium deposits show a close spatial relation to faultline oil fields. The buried Edwards Limestone of Early Cretaceous age contains significant amounts of hydrogen sulfide, which could have migrated upward along faults and served as a precipitant for uranium (Eargle and Weeks, 1961).

Studies of the sulfur isotopic compositions of iron disulfides (pyrite and marcasite) associated with the uranium deposits show that pre-ore and post-ore sulfides probably formed from sour gas derived from the Edwards Limestone (Busche and others, 1981; Goldhaber and others, 1979; Ludwig and others, 1982; Reynolds and Goldhaber, 1978), but ore-stage iron disulfide has isotopically light sulfur, unlike the sour gas of the Edwards. Some of the deposits contain carbonaceous material; in these deposits, carbonaceous material may have served as a food source for sulfate-reducing bacteria, which can generate isotopically light sulfide. Such sulfide can combine with iron to form pyrite with isotopically light sulfur.

\section{Temple Mountain, Utah}

The Temple Mountain uranium district is located in central Utah on the southeast flank of the San Rafael
Swell, a large anticlinal structure (fig. 1, no. 12). Temple Mountain is the site of a collapse structure that is conspicuously bleached and otherwise altered and mineralized. Mineralization in the collapse structure has a wide stratigraphic range. Adjacent to the collapse is a uranium mineral belt confined to the Upper Triassic Moss Back Member of the Chinle Formation. The lithology of the Moss Back is conglomeratic sandstone interbedded with mudstone. The distribution of mineralization in the mineral belt suggests an oil-water interface (Keys and White, 1956).

One of the earliest reports of uraniferous asphaltite was from Temple Mountain (Hess, 1922). Asphaltite is found in the collapse structure as well as in the mineral belt. Uraniferous asphaltite is an enigmatic substance that is not clearly related either to coal or petroleum; however, Breger (1955) and Breger and Deul (1959) concluded from their studies that asphaltite is related to coal and not to crude oil. It resembles thucholite in many respects (Davidson and Bowie, 1951; Ellsworth, 1928) but lacks thorium. Infrared spectra of asphaltites, characterized by small absorption peaks and low transmittance of infrared radiation, do not conclusively prove either a coal or a petroleum relation (Hawley and others, 1965), but association of oil or asphalt with asphaltite over a wide stratigraphic interval suggests a genetic relation. Although carbonaceous plant material is present in the district, it is not as abundant as oil. The geologic relations indicate that a closer connection exists between asphaltite and oil than between asphaltite and carbonaceous plant material.

\section{Deposits in the Todilto Limestone Member of the Wanakah Formation of the Grants Area, New Mexico}

The Middle Jurassic Todilto Limestone Member of the Wanakah Formation contains uranium and vanadium in northwestern New Mexico near the town of Grants (fig. 1, no. 32). The Todilto averages about $9 \mathrm{~m}(30 \mathrm{ft})$ in thickness and consists of a basal platy zone, a medial crinkly zone, and an upper massive zone. Intraformational folds of various types are developed in all zones but are best expressed in the basal platy and medial crinkly zones.

Primary Todilto ore consists of uraninite, häggite, purple and black uraniferous fluorite, pyrite, and barite (Bell, 1956; Weeks and Truesdell, 1958). Some of the ore is very high grade.

The rock has a fetid odor and is believed by Bell (1956) and Weeks and Truesdell (1958) to contain petroliferous material. Weeks and Truesdell (1958) also noted the presence of altered, brittle, asphaltic material in recrystallized calcite. 


\section{GEOLOGY OF URANIUM OCCURRENCES THAT SHOW POSITIVE ASSOCIATIONS WITH PETROLIFEROUS MATERIALS}

\section{Carlsbad, New Mexico}

Uraniferous asphaltite nodules occur in back-reef dolomites of Late Permian age near Carlsbad in southeastern New Mexico (fig. 1, no. 36). The mineralized rocks contain patches of residual oil.

Radiation damage to the nodules has caused physical and chemical changes such as infusibility, insolubility, dehydrogenation, and cross-linking of carbon atoms (Charlesby, 1954; Pierce and Rosholt, 1961), which makes the nature of the original material indeterminate; the original material was probably oil or asphalt.

\section{Chalone Creek, California}

The Chalone Creek uranium occurrence is located in San Benito County in western California (fig. 1, no. 1). An asphalt-bearing arkose bed crops out along a small tributary of Chalone Creek and dips $40^{\circ} \mathrm{E}$. The arkose is the basal part of an unnamed Pliocene marine formation. Three samples of the arkose were tested and averaged 11.18 percent oil, 0.48 percent ash in oil, and 0.182 percent uranium in ash (Hail and others, 1956). Although the uraniferous asphalt is not ore, it exemplifies the close correlation that can exist between oil and uranium.

\section{Edna, California}

The Edna uranium occurrence is located in San Luis Obispo County in southwestern California (fig. 1, no. 2). Deposits of asphalt-bearing sandstone occur in the Pismo Formation of late Miocene and Pliocene ages. The Pismo is composed of conglomerate, arkosic sandstone, diatomaceous sandstone, sandy and silty shale, diatomaceous shale, siliceous shale, and chert. "The asphalt is irregularly distributed in lenticular and discontinuous beds of arkosic sandstone which range in thickness from a few feet to almost 300 feet," according to Hail $(1957$, p. 64).

The uranium content of seven asphalt-bearing sandstone samples ranges from 0.035 to 1.9 percent and averages 0.376 percent in the ash of the extracted oil (Hail, 1957). This is an excellent example of the affinity of uranium for asphalt.

\section{Ellis, Missouri}

The Ellis uranium occurrence is located in a quarry in Vernon County in western Missouri (fig. 1, no. 42). Asphalt deposits occur in lenticular sandstone beds in the
Middle Pennsylvanian Cherokee Shale. The rock containing the asphalt is mainly fine-grained micaceous quartzose sandstone (Hail, 1957). Three samples of asphaltic rock were tested and averaged 4.64 percent oil, 0.62 percent ash in oil, and 0.145 percent uranium in ash (Hail and others, 1956).

\section{Huntsville, Arkansas}

The Huntsville uranium occurrence is an asphaltic sandstone located in Madison County in northwestern Arkansas on the southern side of the Ozark Dome (fig. 1, no. 44). Preliminary analyses of the asphaltic sandstone show 2.51 percent oil, 1.11 percent ash, $12 \mathrm{ppm}$ uranium in oil, and 0.11 percent uranium in ash (Beroni, 1954). The asphaltic material occurs in a coarse-grained sandstone of the Lower Pennsylvanian Hale Formation. Little is known about the geology of the occurrence, but a positive relation apparently exists between asphalt and uranium.

\section{Los Alamos, California}

The Los Alamos uranium occurrence is located in Santa Barbara County in southwestern California (fig. 1, no. 3). Thick beds of asphalt-bearing sandstone crop out along the front of the San Rafael Mountains (Hail, 1957). The asphalt-bearing beds are in the Sisquoc Formation of Miocene and Pliocene ages. The Sisquoc Formation is composed mostly of medium- to fine-grained sandstone with thin beds of conglomerate. The asphaltbearing beds are estimated to underlie an area of at least $13 \mathrm{~km}^{2}\left(5 \mathrm{mi}^{2}\right)$ (Hail, 1957). Tests of seven samples of asphalt-bearing rock averaged 12.40 percent oil, 0.78 percent ash in oil, and 0.081 percent uranium in ash (Hail and others, 1956). The highest concentration of uranium in oil was $27.4 \mathrm{ppm}$.

\section{McKittrick, California}

The McKittrick uranium occurrence is located in Kern County in southwestern California (fig. 1, no. 4). Large deposits of asphalt in the form of asphalt-bearing sandstone, asphalt-bearing alluvium, oil seeps, and vein asphalt crop out near McKittrick (Hail, 1957). The deposits occur in the Miocene Monterey Shale, the Pliocene Etchegoin Formation, the Pliocene and Pleistocene Tulare Formation, and Holocene alluvium. The rocks are highly folded and faulted, and the asphalt deposits, as well as a small producing oil field, are associated with these structures (Hail, 1957). Five samples tested averaged 26.91 percent oil, 1.66 percent ash in oil, and 0.047 percent uranium in ash (Hail and others, 1956). 


\section{Southwestern Oklahoma}

Uraniferous carbonaceous nodules are found in Kiowa County in southwestern Oklahoma on the northeast flank of the Wichita Mountains (fig. 1, no. 37). They occur in red beds of the Permian Hennessey Shale. The nodules are black and botryoidal, have a dull luster, and range to $4.5 \mathrm{~cm}(1.8 \mathrm{in}$.) in diameter (Curiale and others, 1983). The irradiation of original organic material by uranium contained in the nodules has altered the physical and chemical properties of the organics beyond recognition.

Oil seeps are common in Kiowa County, but local coal deposits or preserved plant debris are not in evidence. Spectrographic analyses of the nodules show an assemblage of trace metals similar to that found in local crude oils, namely uranium, vanadium, aluminum, iron, nickel, cobalt, lead, arsenic, and yttrium (Hill, 1957), and infrared spectra of the nodules show features indicative of both coal and petroleum. X-ray patterns show that the nodules contain smaltite, uraninite, and possibly coffinite (Hill, 1957). On the basis of carbon isotope data and geologic field relations, Curiale and others (1983) proposed an oil-related origin for the uraniferous nodules.

\section{Sulphur, Oklahoma}

The Sulphur uranium occurrence is located in Murray County in southern Oklahoma (fig. 1, no. 39). Asphalt-bearing sandstone and limestone beds crop out about $8 \mathrm{~km}(5 \mathrm{mi})$ south of Sulphur over an area of about $2.6 \mathrm{~km}^{2}\left(1 \mathrm{mi}^{2}\right)$ (Hail, 1957). Most of the asphalt occurs in the Middle Ordovician Oil Creek Formation. The major structure in the area is a complexly faulted, northeastward-trending anticline (Hail, 1957). Seven samples tested averaged 4.56 percent oil, 0.70 percent ash in oil, and 0.043 percent uranium in ash (Hail and others, 1956).

\section{Vernal, Utah}

The Vernal uranium occurrence is located in Uintah County in northeastern Utah (fig. 1, no. 10). Asphalt deposits occur mainly in the basal part of the Eocene Uinta Formation and are exposed along Asphalt Ridge in the Uinta basin (Hail, 1957), although some of the asphalt-bearing beds may be in the upper part of the Upper Cretaceous Mesaverde Formation (Hail, 1957). The Uinta Formation lies unconformably on the Mesaverde and consists of shale, sandstone, and coarse siliceous conglomerate. The upper part of the Mesaverde Formation consists mainly of medium-grained sandstone. Twenty-one samples of asphaltic rock gave an average oil content of 8.10 percent, average ash in oil of 2.68 percent, and average uranium in ash of 0.028 percent (Hail and others, 1956).

\section{GEOLOGY OF URANIUM DISTRICTS THAT MAY SHOW POSITIVE ASSOCIATIONS WITH PETROLIFEROUS MATERIALS}

\section{Copper Mountain, Wyoming}

The Copper Mountain uranium district is located in north-central Wyoming on the southeast flank of the Owl Creek Mountains (fig. 1, no. 18). The district gets its name from the small, late 1800's and early 1900 's, copper, gold, and silver mines that exploited the quartz veins in the area's Precambrian rocks.

Uranium occurs in two different units: (1) in the conglomeratic and bentonitic Eocene Teepee Trail Formation and (2) in Precambrian rocks mostly associated with fractures. Asphaltic material is reported from both units, but little is known about its occurrence. Carbonaceous plant material is abundant in the Teepee Trail where uranium is present.

Uranium minerals reported from the area are autunite, meta-autunite, coffinite, uraninite-sooty pitchblende, and uranophane (Yellich and others, 1978).

\section{Crooks Gap, Wyoming}

The Crooks Gap uranium district is located in south-central Wyoming in the northeastern part of the Great Divide basin (fig. 1, no. 20). The host for the uranium deposit is the Paleocene and Eocene Battle Spring Formation (Pipiringos, 1955), which is composed of moderately dipping arkosic sandstone, conglomerate, and mudstone. The Battle Spring is overlain by a conspicuous sequence of nearly horizontal boulder beds known as the Eocene Crooks Gap Conglomerate (Love, 1970).

Uranium deposits are of the roll type and seem to be closely associated with carbonaceous material (Stephens, 1964). Bleaching and red hematitic alteration, intimately related to the roll deposits, are conspicuous features of the district. Petroliferous materials have not been reported from the uranium deposits, but oil fields are nearby. The oil fields could have provided hydrogen sulfide or other petroliferous materials that would serve as uranium reductants. However, note that the oil fields may or may not bear a relation to the uranium deposits.

\section{Gas Hills, Wyoming}

Located in central Wyoming, the Gas Hills district is one of the most productive uranium areas of the United States (fig. 1, no. 19). It is situated in the southern part of the Wind River basin due north of the Crooks Gap district. 
Uranium occurs in the upper part of the gently dipping Eocene Wind River Formation. The part of the Wind River Formation that is environmentally favorable to uranium has been included in the Puddle Springs Arkose Member (Soister, 1968). Large volumes of bleached rock are spatially related to roll-type ore deposits. Carbonaceous material is present in the deposits but not in abundance.

The Gas Hills anticline exposes rocks that are older than the Wind River Formation, and oil and gas tests in the vicinity of the anticline have proven noncommercial. However, several natural gas seeps have been reported and at least one contains hydrogen sulfide (Grutt, 1957). Natural gas pockets are often encountered during drilling for uranium, which suggests that they may be widespread. If natural gases containing hydrogen sulfide were discharged in sufficient quantity into ground water, an effective precipitant for iron disulfide and uranium would have been available. The role of natural gases in the formation of these deposits is speculative because direct evidence is lacking.

\section{Lisbon Valley, Utah}

The Lisbon Valley uranium district is located in southeastern Utah near the Colorado State line (fig. 1, no. 14). This highly productive district yields ore from the Lower Permian Cutler Formation, the basal part of the Upper Triassic Chinle Formation, and the Salt Wash Member of the Upper Jurassic Morrison Formation, although the largest quantity of ore has come from the Moss Back Member of the Chinle Formation.

Lisbon Valley is situated along an elongate, longitudinally faulted, breached, salt-cored anticline, a part of the Paradox fold and fault belt. The uranium ore deposits in the Chinle Formation follow structure contours in such a way that they could indicate a paleo-oil-water interface (Lekas and Dahl, 1956). An oil field is located at depth on the western side of the northwest-trending anticline, nearly underlying some of the uranium deposits in the Chinle and Cutler Formations. Remote sensing of bleaching of the Upper Triassic Wingate Sandstone has shown that a close spatial relation exists with underlying uranium deposits in the Chinle as well as with oil and gas structures (Conel and Niesen, 1981). Sour gas leakage could be responsible for these relations, suggesting a genetic connection between uranium and oil and gas. Carbonaceous material is usually abundant in or near the Chinle ore deposits. Petroliferous material is uncommon but has been reported from some mines in the district (Conel and Niesen, 1981).

\section{Deposits in the Morrison Formation of the Grants Area, New Mexico}

Uranium deposits in the Upper Jurassic Morrison Formation of the Grants area are located along the southern margin of the San Juan Basin in the vicinity of the town of Grants in northwestern New Mexico (fig. 1, no. 31). The Grants uranium region comprises several uranium districts, including Ambrosia Lake, Church Rock, Poison Canyon, and others. Only the deposits of the Morrison Formation are considered here; deposits in the Middle Jurassic Todilto Limestone Member of the Wanakah Formation (fig. 1, no. 32) are treated in a separate section. The Morrison in the area is divided into three members: the Recapture, the Westwater Canyon, and the Brushy Basin. Uranium ore is found in fluvial sandstones of the Westwater Canyon Member and in the basal and upper parts of the Brushy Basin Member.

Two inajor types of ore are in the region: primary or trend ore is characterized by tabular, peneconcordant ore bodies that are rich in amorphous insoluble organic material; whereas the secondary ore is referred to as redistributed or stack ore and is characterized by discordant relations with the host rock, spatial association with faults, roll-front geometry, and generally low content of amorphous organic material.

In the Ambrosia Lake district, unoxidized ore is composed of coffinite and is ubiquitously associated with a dark-colored carbonaceous residue. Zitting and others (1957) reported that the residue is a humic acid that was believed to be formed by the oxidation of asphalt. Birdseye (1957) believed that the Ambrosia Lake dome was the site of a preexisting oil pool that migrated down structure and provided the carbonaceous residue seen in the ores. Researchers generally agree that the carbonaceous material precipitated the uranium in the ores. Granger (1968) stated that the carbonaceous residue is coextensive with primary or trend uranium ore and probably had its origin in humic acids or humates. He found no evidence that petroleum played any role in its development. Jacobs (1970) studied the carbonaceous residue by a number of sophisticated analytical techniques and concluded that the material is of coaly origin and related to humic acids. Although these features describe the Ambrosia Lake district, they apply to the primary ores in most other districts in the Grants area as well.

\section{Rifle Creek, Colorado}

The Rifle Creek vanadium-uranium district is located on the Grand Hogback monocline in northwestern Colorado a short distance northeast of the town of Rifle (fig. 1, no. 28). The deposits are in the moderately dipping Upper Triassic to Lower Jurassic Glen Canyon Sandstone and Middle Jurassic Entrada Sandstone, which are composed mostly of clean, fine-grained sandstone. The Upper Jurassic Morrison Formation also contains vanadium-uranium deposits locally.

Carbonaceous plant material is absent in the Glen Canyon and Entrada deposits but present in the Morrison 
deposits. Petroleum residue occurs in parts of the Entrada and Morrison, and small blebs of asphaltite are scattered along fracture walls in a few places (Fischer, 1960).

The ore deposits occur in three parallel tabular layers separated by barren sandstone: (a) a vanadiumuranium ore layer, (b) a thin galena-clausthalite layer, and (c) a chromium-bearing layer. The ore minerals in these deposits are the vanadium mica roscoelite, vanadiumbearing mixed layer mica-montmorillonite, vanadiumbearing chlorite, montroseite, tyuyamunite or carnotite, and bayleyite (Fischer, 1960).

\section{Shirley Basin, Wyoming}

The Shirley basin uranium district is located in southeastern Wyoming (fig. 1, no. 25) due east of the Crooks Gap uranium district (fig. 1, no. 20) and is a major producer of uranium in the United States. The Eocene Wind River Formation, host rock for the uranium deposits, consists of poorly consolidated gravel, sand, silt, and clay of continental origin. The Wind River is overlain unconformably by tuffaceous claystone, siltstone, and sandstone of the Oligocene White River Formation (Harshman, 1961).

Two mineralized tongues form a belt located just west of a buried ridge of the Wall Creek Sandstone Member of the Upper Cretaceous Frontier Formation. The buried ridge is believed to have exerted control on the favorable lithology of the Wind River Formation. The Wall Creek Sandstone may also have contributed hydrogen sulfide or other petroliferous material to the Wind River Formation.

The deposits are of the roll type and are associated with large tongues of greenish-yellow altered rock (Harshman, 1972). Carbonaceous material is present in and near ore; uraninite is the chief ore mineral.

\section{White Canyon, Utah}

The White Canyon uranium district is located in southeastern Utah on the gently dipping west flank of the Monument upwarp (fig. 1, no. 16). The host rock for the uranium deposits are mostly the sandstones and conglomerates of the Shinarump Member of the Upper Triassic Chinle Formation. Most of the uranium deposits, which have associated copper minerals, occur in Shinarump channels cut into the Lower and Middle(?) Triassic Moenkopi Formation.

The principal uranium ore minerals are uraninite, uranophane, metatorbernite, phosphuranylite, metazeunerite, and a zippeite-like mineral (Thaden and others, 1964). Sulfide minerals associated with the uranium are pyrite, chalcopyrite, sphalerite, galena, bornite, chalcocite, covellite, and marcasite. The best known and largest productive mine in the district was the Happy Jack, which started as a copper mine and subsequently became a uranium mine.

Fossil plant material is present in most of the deposits in the district and is partly replaced by uraninite and sulfides. Near their pinchouts, some beds of the Lower Triassic Hoskinnini Member of the Moenkopi Formation, which underlie the Shinarump Member of the Chinle Formation, are impregnated with a black hydrocarbon that may be stagnant inspissated petroleum (Thaden and others, 1964). This hydrocarbon is not mineralized with uranium.

\section{GEOLOGY OF URANIUM DISTRICTS OR MINES THAT APPARENTLY SHOW NO POSITIVE ASSOCIATIONS WITH PETROLIFEROUS MATERIALS}

\section{Anderson Mine, Date Creek Basin, Arizona}

The Anderson uranium mine is located in the northeastern part of the Date Creek basin in western Arizona (fig. 1, no. 8) and is the largest uranium deposit in the Basin and Range physiographic province. Mineralization has occurred in two lacustrine carbonaceous units that form part of the gently dipping Miocene Chapin Wash Formation. The mineralized Chapin Wash is composed of tuffaceous mudstones, fine-grained sandstones, and silicified marlstones. Uranyl-bearing opaline silica and colloform coffinite have been identified as the main ore minerals (Mueller and Halbach, 1983). Molybdenum, sulfur, vanadium, and organic carbon are concentrated with the products of uranium mineralization (Sherborne and others, 1979).

Fossil plant material is abundant and uranium occurs principally in thinly bedded siltstones rich in carbonaceous or silicified plant material (Otton, 1977). The organic material may have served as a food source for sulfate-reducing bacteria that could generate hydrogen sulfide, a potential precipitant of uranium. Petroliferous materials have not been reported from the area.

\section{Cameron, Arizona}

The Cameron uranium district is located in northcentral Arizona along the southwest flank of the Black Mesa basin (fig. 1, no. 7). Uranium deposits are mainly in the Petrified Forest Member of the Upper Triassic Chinle Formation; a few small deposits are in the Shinarump Member.

Uraninite, meta-autunite, carnotite, zippeite, uranophane, and metatorbernite have been identified 
as ore minerals (Hinckley, 1955). Carbonaceous material commonly occurs with ore, but petroliferous material has not been reported. In a study by Hinckley (1955), the distribution of molybdenum was found to be the best geochemical index of an environment favorable to the occurrence of uranium.

\section{Edgemont, South Dakota}

The Edgemont uranium district is located in the southern Black Hills in extreme southwestern South Dakota (fig. 1, no. 23). All important uranium deposits in the area are in the gently dipping Lower Cretaceous Inyan Kara Group, which is characterized by alternating sandstone, siltstone, and mudstone. Black shales, carbonaceous trash, and arkosic pebble conglomerates are common (King, 1956). Structural terraces are broad ore controls for these deposits.

Primary ore contains uraninite and coffinite. Secondary ore includes carnotite, tyuyamunite, metatyuyamunite, corvusite, and rauvite (Robinson and Gott, 1958).

Pink sandstone is commonly associated with the ore deposits. White bleached sandstone is commonly associated with dark uranium and vanadium minerals (Bell and Bales, 1955).

Carbonized plant material is abundant in some deposits and absent in others. Asphaltic material has not been reported from the Inyan Kara rocks, but petroliferous material has been recorded from other units. Hydrogen sulfide has been found in artesian waters in the Inyan Kara by Gott and others (1974), but its origin has been attributed to action by sulfate-reducing bacteria rather than to oil fields.

\section{Highland Deposit, Powder River Basin, Wyoming}

The Highland uranium deposit is located in the southern part of the Powder River basin, northeastern Wyoming (fig. 1, no. 22). The Powder River basin is a large asymmetric syncline. The nearly flat lying arkosic sandstones of the upper part of the Paleocene Fort Union Formation or the lower part of the Paleocene and Eocene Wasatch Formation are hosts for the ore body, which is closely associated with red, yellow, and yellowish-brown oxidized strata and with light-gray to gray-buff reduced strata. The ore body is composed of uraninite and coffinite and forms rolls, tabular deposits, and elliptical or dish-shaped deposits (Langen and Kidwell, 1974).

Organic material in the form of carbonized wood and lignite is commonly associated with ore. Petroliferous material has not been reported from the deposit.

\section{Mauch Chunk, Pennsylvania}

The Mauch Chunk (Jim Thorpe) uranium occurrence is located in eastern Pennsylvania in the border zone between the main folded belt of the Appalachians and the relatively undisturbed Pocono Plateau (fig. 1, no. 47) (McCauley, 1957). The Mauch Chunk occurrence at Mt. Pisgah is found in a coarse graywacke conglomerate near the base of the Lower to Middle Pennsylvanian Pottsville Formation (Klemic and Baker, 1954).

The deposits consist of oxidized and unoxidized ore minerals, but carbonaceous material is present and probably acted as an ore control. Petroliferous material has not been reported from the area.

\section{Monument Hill, Powder River Basin, Wyoming}

The Monument Hill uranium district is located in the southern part of the Powder River basin in northeastern Wyoming (fig. 1, no. 21). The deposits are in nearly flat lying fluvial arkosic sandstone units of the lower part of the Paleocene and Eocene Wasatch Formation. Although the ore bodies form rolls, variations of the C-roll or S-roll are common and stair-step rolls are present (Davis, 1969). Adjacent to the roll front is a limonite or bleached zone, and adjacent to the limonite zone is a hematite zone. The red to pink hematite zone is distinctive and has been used as a guide to ore deposits (Sharp and Gibbons, 1964).

Organic carbon is present near ore, but petroliferous material has not been reported. The ore minerals in the oxidized zone are carnotite, tyuyamunite, liebigite, zellerite, uranophane, autunite, and, in the reduced zone, uraninite (Sharp and Gibbons, 1964).

\section{Monument Valley, Arizona}

The Monument Valley uranium-vanadium district is located in southeastern Utah and northeastern Arizona along the southern part of the Monument upwarp, a large asymmetric, north-trending anticline (fig. 1, no. 17). The uranium-vanadium deposits are all in scour channels of the Shinarump Member of the Upper Triassic Chinle Formation which cut into the Lower and Middle(?) Triassic Moenkopi Formation or the De Chelly Sandstone Member of the Permian Cutler Formation.

A close spatial relation exists between pockets of uranium ore, channel fill, and carbonized plant material (Witkind and Thaden, 1963). Petroliferous material is apparently absent. 


\section{Orphan Mine, Grand Canyon, Arizona}

The Orphan uranium-copper mine is located on the south rim of Grand Canyon National. Park in northcentral Arizona (fig. 1, no. 6). The ore body is confined to a breccia pipe that probably originated through solution collapse of sediments. The Orphan pipe is not the only mineralized pipe in the Grand Canyon country; a number of unmineralized pipes also occur. The Orphan pipe penetrates more than $457 \mathrm{~m}(1,500 \mathrm{ft})$ of Permian Coconino Sandstone and Hermit Shale, Permian and Pennsylvanian Supai Group, and perhaps the upper part of the Mississippian Redwall Limestone (Gornitz and Kerr, 1970).

Metallic minerals in the ores include uraninite, chalcocite, digenite, covellite, chalcopyrite, bornite, tennantite, pyrite, marcasite, sphalerite, galena, niccolite, and rammelsbergite (Gornitz and Kerr, 1970). Carbonaceous material is present in some of the ore (C. G. Bowles, oral commun., 1984), but petroliferous material has not been reported.

\section{Tallahassee Creek, Colorado}

The Tallahassee Creek uranium district is located in Fremont County in south-central Colorado (fig. 1, no. 29) and lies in the southern part of the Echo Park graben. Host rocks for the ore bodies are the upper Eocene Echo Park Alluvium and the lower Oligocene Tallahassee Creek Conglomerate. Uranium was transported in ground water to favorable sites where it was deposited in a reducing environment controlled by carbonaceous material and associated pyrite (Dickinson, 1981). Reserves of $\mathrm{U}_{3} \mathrm{O}_{8}$ are greater than combined reserves and production at the Schwartzwalder deposit in the Ralston Buttes district in Jefferson County, Colo. (Dickinson, 1981). The main ore minerals are uraninite and coffinite (Cyprus Mines Corporation, 1980). Petroliferous material has not been reported from the district.

\section{Uravan Mineral Belt, Colorado}

The Uravan mineral belt is located in southwestern Colorado (fig. 1, no. 13) and consists of carnotite deposits in the Upper Jurassic Morrison Formation that have a closer spacing, larger size, and higher grade than those in adjoining areas (Fischer and Hilpert, 1952). Vanadiumuranium deposits, fossil logs, and ore rolls have a dominant orientation normal to the mineral belt.

Exploration for ore is guided by thickness and color of the ore-bearing sandstone, color of mudstone associated with the sandstone, and the presence of abundant carbonaceous plant material within the ore-bearing sandstone (Weir, 1952). A minimum thickness of $12 \mathrm{~m}$ (40 ft) is considered favorable for ore-bearing sandstone. The sandstone is mostly pale to light yellowish brown, speckled with limonite stain; a pronounced red color is generally indicative of unfavorable strata. Mudstone associated with the ore-bearing sandstone is gray or greenish gray instead of the normal red color. The presence of carbonized plant remains is indicative of favorable strata and suggests the proximity of ore. Petroliferous material has not been reported from the Uravan mineral belt.

\section{GEOLOGY OF METALLIFEROUS DISTRICTS OTHER THAN URANIUM THAT SHOW POSITIVE ASSOCIATIONS WITH PETROLIFEROUS MATERIALS}

\section{Lake Alice Cu-Ag-Zn District, Wyoming}

At the Lake Alice district in western Wyoming (fig. 1, no. 9) and at two other locations more than $80 \mathrm{~km}$ (50 $\mathrm{mi})$ to the north, copper, silver, and zinc occur at or near the top of the Nugget Sandstone of Triassic(?) and Jurassic(?) age (Love and Antweiler, 1973). All localities are within the thrust belt of western Wyoming. Mineralization is in sandstone that was originally red but was subsequently altered to gray, brown, black, and green.

No fossil plant material is present in the Nugget Sandstone, but its presence is well documented in many red-bed copper deposits in the western United States. No oil has been reported from the Nugget within the Lake Alice area, but its original presence is suggested by bleaching and the oil content at several places in the overlying limestone and dolomite breccia. Bleaching and oil staining may be useful guides to prospecting for metallic mineral deposits in certain types of sedimentary rocks (Love and Antweiler, 1973).

\section{Picher-Miami Field of Tri-State Pb-Zn District, Oklahoma-Kansas}

The Picher-Miami field of the Tri-State $\mathrm{Pb}-\mathrm{Zn}$ district is located in extreme northeastern Oklahoma and extreme southeastern Kansas (fig. 1, no. 43). The TriState district has been a major producer of lead and zinc in the United States. The ore bodies occur in the Mississippian Boone Formation, a carbonate sequence composed of limestone, dolomite, and chert.

In the Picher-Miami field, oil occurs in the underground mine workings and appears to have its origin in the rocks overlying the ore bodies. The oil reservoirs are found in traps beneath shale, ordinarily at the tops of domes (Fowler, 1933). The relation of oil and ore may or may not be genetically controlled by structure. 
Upper Mississippi Valley Pb-Zn District, Southwestern Wisconsin and Adjoining States

The upper Mississippi Valley $\mathrm{Pb}-\mathrm{Zn}$ district is located in southwestern Wisconsin, northwestern Illinois, and northeastern Iowa (fig. 1, no. 46). The ore is generally fracture controlled. The rocks in the district dip very gently to the southwest. The main ore-bearing stratigraphic unit is the Galena Dolomite of Middle Ordovician age. The basal part of the Galena Dolomite contains layers of organic shale, or "oil rock," that burn with a petroliferous odor. The organic shale is believed by Bain (1906) to be the agent responsible for the precipitation of lead and zinc sulfides, and Barton (1967) believed that methane or other related organic material played an important role in the precipitation of Mississippi Valley ores. Cox (1911) held that the Upper Ordovician Maquoketa Shale, which overlies the Galena Dolomite, was the source of the lead and zinc ores.

The primary minerals in the deposits are galena, sphalerite, marcasite, pyrite, and chalcopyrite. Secondary minerals are smithsonite, hydrozincite, calamine, cerussite, anglesite, sulphur, wad, limonite, and melanterite. Gangue minerals are calcite, dolomite, selenite, barite, and quartz.

\section{GEOLOGY OF METALLIFEROUS DISTRICTS OTHER THAN URANIUM THAT MAY SHOW POSITIVE ASSOCIATIONS WITH PETROLIFEROUS MATERIALS}

\section{Bent (Virginia) Red-Bed(?) Cu Deposit, New Mexico}

The Bent, or Virginia, copper deposit is located in northern Otero County in southern New Mexico near the Bent post office (fig. 1, no. 35). Copper minerals occur in a sandstone bed, probably in the Permian Chupadera Formation, a term abandoned and replaced by Artesia Group, as well as in veins in an underlying diorite intrusive (Soulé, 1956). The association with an intrusive suggests that these copper deposits may not be of the redbed type. Chalcocite, malachite, and azurite are the main ore minerals. A black, resinous hydrocarbon was reported in the ores.

\section{Fredericktown Pb District, Missouri}

The Fredericktown lead-mining district is located in Madison County, southeastern Missouri (fig. 1, no. 45). Uraniferous albertite, which is reported from the district, contains 3.79 percent uranium in 20.42 percent ash (Hill, 1953). In the Glossary of Geology and Related Sciences $(1960$, p. 6), albertite is defined as "a black variety of bitumen with a brilliant luster that has a conchoidal fracture and is practically insoluble in alcohol." The albertite is apparently not genetically related to fresher, more viscous oil that occurs in small quantities as cavity fillings in the Upper Cambrian Bonneterre Dolomite, which overlies the albertite deposits (Hill, 1953).

\section{Silver Reef District, Utah}

The Silver Reef district is located near Zion National Park in Washington County, southwestern Utah (fig. 1, no. 5). The district is unique in the United States in that commercial silver ore is associated with minor copper, uranium, vanadium, and selenium minerals in sandstone (Proctor, 1953). Silver ore is found in the Silver Reef sandstone of Proctor (1953), an informal unit in the Upper Triassic Chinle Formation, on the limbs and noses of folds.

Cerargyrite is the dominant ore mineral in the district, but malachite, azurite, chalcocite, and carnotite are also present (Proctor, 1953). The ore minerals, especially copper minerals, are closely associated with plant fossils including fossil tree trunks. Genesis of the deposits is uncertain but likely is similar to the genesis of the uranium-vanadium deposits of the Colorado Plateau. Petroliferous material has not been reported from the district, but the association of mineralized rock with an anticlinal structure suggests a relationship with oil or gas.

\section{GEOLOGY OF METALLIFEROUS DISTRICTS OTHER THAN URANIUM THAT PROBABLY DO NOT SHOW POSITIVE ASSOCIATIONS WITH PETROLIFEROUS MATERIALS}

\section{Guadalupe (Stauber) Red-Bed Cu Deposit, New Mexico}

The Guadalupe (Stauber) copper deposit is located in Guadalupe County in east-central New Mexico near the town of Santa Rosa (fig. 1, no. 34). Copper mineralization occurred in the generally flat lying Santa Rosa Sandstone at the base of the Upper Triassic Dockum Group (Soulé, 1956). The ore minerals are chalcocite, malachite, azurite, and copper pitch. Replacement of carbonaceous material reportedly appears to be unimportant in these deposits (Soulé, 1956). Petroliferous materials have not been reported.

\section{Pintada Lode Red-Bed Cu Deposits, New Mexico}

The Pintada Lode copper deposits are located in Guadalupe County in east-central New Mexico near Santa 
Rosa (fig. 1, no. 33). The Pintada Lode deposits are about $8 \mathrm{~km}(5 \mathrm{mi})$ northwest of the Guadalupe copper deposits. Copper mineralization occurred in fine-grained, flat-lying sandstone members of the Permian Chupadera Formation (now called Artesia Group) (Soulé, 1956). Chalcocite and malachite are moderately abundant. Neither carbonaceous nor petroliferous materials have been reported from the area. The mechanism of precipitation of the ore minerals is not known.

\section{Sierra Nacimiento Cu Deposits, New Mexico}

The Sierra Nacimiento copper deposits are located in northern New Mexico east of the San Juan Basin near the town of Cuba (fig. 1, no. 30). Copper minerals are closely associated with fossil logs in the Agua Zarca Sandstone Member of the Upper Triassic Chinle Formation. Small amounts of native silver are also present. The Agua Zarca consists of white to buff, fine- to very coarse grained, thick-bedded, quartzose sandstone sandwiched between red beds (Woodward and others, 1974).

Carbonaceous plant material appears to have been the most important factor in controlling mineralization (Woodward and others, 1974). Petroliferous materials have not been reported.

\section{DISCUSSION}

Can the occurrence of uranium be used to predict the occurrence of petroleum? The answer to this question is a qualified no. There are certainly some good examples of uranium and petroleum occurring together: Cement, Okla.; McKittrick, Calif.; Palangana salt dome, Texas; and Temple Mountain, Utah. Furthermore, some petroleum explorationists claim that oil fields have radioactive halos and the detection of these halos is an exploration guide. However, many cases also exist where uranium shows no apparent connection with petroleum; some examples are the Anderson mine, Date Creek basin, Arizona; Edgemont, S. Dak.; Mauch Chunk, Pa.; Monument Hill, Powder River basin, Wyoming; Monument Valley, Ariz.; Orphan mine, Grand Canyon, Ariz.; Tallahassee Creek, Colo.; and Uravan mineral belt, Colorado. A positive relation exists between uranium and organic matter, and the organic matter may be either carbonaceous plant or petroliferous material. Where uranium exists in sedimentary rocks with neither carbonaceous nor petroliferous material is a rare circumstance.

Can the occurrence of oil and gas be used to predict the occurrence of uranium? The answer is a definite no. Numerous examples exist of oil and gas fields with no associated uranium throughout the United States but especially in the midcontinent region.
Is uraniferous asphaltite petroleum-derived or coalderived material? Some studies have concluded that uraniferous asphaltite is coal derived, largely on the basis of infrared spectroscopy and organic elemental analysis. Others have concluded that the material is petroleum derived on the basis of geologic relationships and carbon isotopic analyses. Therefore, a case can be made for either-although perhaps more convincingly for coalderived material. Uraniferous asphaltite may possibly be derived from either petroleum or coal, depending on availability and chemistry.

\section{CONCLUSIONS}

A number of uraniferous and nonuraniferous metallized localities show positive associations with petroliferous materials. Some of the uraniferous localities are mining districts or deposits, and some are simply isolated occurrences of uranium. The districts or deposits are Cement, Okla.; Elk Ridge, Utah; Lance Creek, Wyo.; Lone Tree deposit, San Rafael Swell, Utah; Maybell, Colo.; Palangana salt dome, Texas; Poison basin, Wyoming; south Texas; Temple Mountain, Utah; and deposits in the Jurassic Todilto Limestone Member of the Wanakah Formation of the Grants area, New Mexico. The occurrences are Carlsbad, N. Mex.; Chalone Creek, Calif.; Edna, Calif.; Ellis, Mo.; Huntsville, Ark.; Los Alamos, Calif.; McKittrick, Calif.; southwestern Oklahoma; Sulphur, Okla.; and Vernal, Utah. The nonuraniferous metallized localities that show positive associations with petroliferous materials are the Lake Alice $\mathrm{Cu}-\mathrm{Ag}-\mathrm{Zn}$ district, Wyoming; the Picher-Miami field of the Tri-State $\mathrm{Pb}-\mathrm{Zn}$ district, Oklahoma-Kansas; and the Upper Mississippi Valley $\mathrm{Pb}-\mathrm{Zn}$ district, southwestern Wisconsin and adjoining States.

Some uranium districts and nonuraniferous metallized localities show possible positive associations with petroliferous materials. The districts are Copper Mountain, Wyo.; Crooks Gap, Wyo.; Gas Hills, Wyo.; deposits in the Upper Jurassic Morrison Formation of the Grants area, New Mexico; Lisbon Valley, Utah; Rifle Creek, Colo.; Shirley basin, Wyoming; and White Canyon, Utah. The nonuraniferous localitites are Bent (Virginia) red-bed(?) $\mathrm{Cu}$ deposit, New Mexico; Fredericktown $\mathrm{Pb}$ region, Missouri; and Silver Reef, Utah.

Some uranium districts and nonuraniferous metallized localities show no known positive associations with petroliferous materials. The uranium districts or mines are the Anderson mine, Date Creek basin, Arizona; Cameron, Ariz.; Edgemont, S. Dak.; Highland deposit, Powder River basin, Wyoming; Mauch Chunk, Pa.; Monument Hill, Powder River basin, Wyoming; Monument Valley, Ariz.; Orphan mine, Grand Canyon, Ariz.; 
Tallahassee Creek, Colo.; and Uravan mineral belt, Colorado. The nonuraniferous localities are the Guadalupe (Stauber) red-bed Cu deposit, New Mexico; the Pintada Lode red-bed $\mathrm{Cu}$ deposits, New Mexico; and the Sierra Nacimiento $\mathrm{Cu}$ deposit, New Mexico.

Several deposits contain the enigmatic material known as uraniferous asphaltite. Uraniferous asphaltite may be either coal-derived or petroleum-derived material. A more definitive origin does not seem warranted by the available data.

\section{REFERENCES CITED}

Allen, R.F., and Thomas, R.G., 1984, The uranium potential of diagenetically altered sandstones of the Permian Rush Springs Formation, Cement district, southwest Oklahoma: Economic Geology, v. 79, no. 2, p. 284-296.

Bain, H.F., 1906, Zinc and lead deposits of the upper Mississippi Valley: U.S. Geological Survey Bulletin 294, 155 p.

Barthauer, G.L., Rulfs, C.L., and Pearce, D.W., 1953, Investigation of thucholite: American Mineralogist, v. 38, nos. 9,10, p. 802-814.

Barton, P.B., Jr., 1967, Possible role of organic matter in the precipitation of the Mississippi Valley ores, in Brown, J.S., ed., Genesis of stratiform lead-zinc-barite-fluorite deposits (Mississippi Valley type deposits): Economic Geology Monograph 3, p. 371-378.

Bell, Henry, III, and Bales, W.E., 1955, Uranium deposits in Fall River County, South Dakota: U.S. Geological Survey Bulletin 1009-G, p. 211-233.

Bell, K.G., 1956, Uranium in precipitates and evaporites, in Page, L.R., Stocking, H.E., and Smith, H.B., compilers, Contributions to the geology of uranium and thorium by the U.S. Geological Survey and Atomic Energy Commission for the United Nations International Conference on Peaceful Uses of Atomic Energy, Geneva, Switzerland, 1955: U.S. Geological Survey Professional Paper 300, p. 381-386.

1960, Uranium and other trace elements in petroleums and rock asphalts: U.S. Geological Survey Professional Paper 356-B, p. 45-65.

Beroni, E.P., 1954, Reconnaissance for uranium in the United States, south-central district, in Geologic investigations of radioactive deposits, Semiannual progress report, December 1, 1953 to May 31, 1954: U.S. Geological Survey TEI-440, issued by U.S. Atomic Energy Commission Technical Information Service, Oak Ridge, Tenn., p. 168-171.

Birdseye, H.S., 1957, The relation of the Ambrosia Lake uranium deposits to a pre-existing oil pool, in Four Corners Geological Society Guidebook 2nd Field Conference, 1957: p. 26-29.

Breger, I.A., 1955, Association of uranium with a naturally occurring coal extract [abs.]: Geological Society of America Bulletin, v. 66, no. 12, pt. 2, p. 1534.

Breger, I.A., and Deul, Maurice, 1959, Association of uranium with carbonaceous materials, with special reference to Temple Mountain region, in Garrels, R.M., and Larson,
E.S., 3d, compilers, Geochemistry and mineralogy of the Colorado Plateau uranium ores: U.S. Geological Survey Professional Paper 320, p. 139-149.

Bromley, C.P., 1955, Preliminary geologic reconnaissance in the Lance Creek area, Niobrara County, Wyoming: U.S. Atomic Energy Commission RME-1066 (Revised), issued by Technical Information Service, Oak Ridge, Tenn., $16 \mathrm{p}$.

Busche, F.D., Goldhaber, M.B., and Reynolds, R.L., 1981, Fault leaked $\mathrm{H}_{2} \mathrm{~S}$ and the origin of south Texas uranium deposits-Implications of sulfur isotopic studies: Geological Society of America Abstracts with Programs, v. 13, p. 234.

Charlesby, A., 1954, The cross-linking and degradation of paraffin chains by high-energy radiation: Proceedings of the Royal Society of London, series A, v. 222, p. 60-74.

Conel, J.E., and Niesen, P.L., 1981, Remote sensing and uranium exploration at Lisbon Valley, Utah: 1981 International Geoscience and Remote Sensing Symposium, v. 1, p. 318-324.

Cox, G.H., 1911, The origin of the lead and zinc ores of the upper Mississippi Valley district, Part II: Economic Geology, v. 6, no. 6, p. 582-603.

Curiale, J.A., Bloch, Salman, Rafalska-Bloch, Janina, and Harrison, W.E., 1983, Petroleum-related origin for uraniferous organic-rich nodules of southwestern Oklahoma: American Association of Petroleum Geologists Bulletin, v. 67, no. 4, p. 588-608.

Cyprus Mines Corporation, 1980, The Hansen project, in Chenoweth, W.L., ed., Colorado uranium field trip guidebook 1980: American Association of Petroleum Geologists, Denver, Colo., p. 12-18.

Davidson, C.F., 1955, Concentration of uranium by carbon compounds: Economic Geology, v. 50, no. 8, p. 879-880.

Davidson, C.F., and Bowie, S.H.U., 1951, On thucholite and related hydrocarbon-uraninite complexes, with a note on the origin of the Witwatersrand gold ores: Great Britain Geological Survey Bulletin 3, p. 1-19.

Davis, J.F., 1969, Uranium deposits of the Powder River Basin, in Contributions to Geology: Wyoming Geological Survey, v. 8 , no. 2 , pt. 1 , p. 131-141.

Dickinson, K.A., 1981, Geologic controls of uranium mineralization in the Tallahassee Creek uranium district, Fremont County, Colorado: The Mountain Geologist, v. 18 , no. 4, p. 88-94.

Donovan, T.J., 1974, Petroleum microseepage at Cement, Oklahoma-Evidence and mechanism: American Association of Petroleum Geologists Bulletin, v. 58, no. 3, p. 429-446.

Eargle, D.H., Dickinson, K.A., and Davis, B.O., 1975, South Texas uranium deposits: American Association of Petroleum Geologists Bulletin, v. 59, no. 5, p. 766-779.

Eargle, D.H., and Weeks, A.D., 1961, Possible relation between hydrogen sulfide-bearing hydrocarbons in fault-line oil fields and uranium deposits in the southeast Texas Coastal Plain, in Geological Survey research 1961: U.S. Geological Survey Professional Paper 424-D, p. D7-D9.

Ellsworth, H.V., 1928, Thucholite, a remarkable primary carbon mineral from the vicinity of Parry Sound, Ontario: American Mineralogist, v. 13, no. 8, p. 419-439. 
Erickson, R.L., Myers, A.T., and Horr, C.A., 1954, Association of uranium and other metals with crude oil, asphalt, and petroliferous rock: American Association of Petroleum Geologists Bulletin, v. 38, no. 10, p. 2200-2218.

Fischer, R.P., 1960, Vanadium-uranium deposits of the Rifle Creek area, Garfield County, Colorado, with a section on Mineralogy, by Theodore Botinelly: U.S. Geological Survey Bulletin 1101, $52 \mathrm{p}$.

Fischer, R.P., and Hilpert, L.S., 1952, Geology of the Uravan mineral belt: U.S. Geological Survey Bulletin 988-A, p. 1-13.

Fowler, G.M., 1933, Oil and oil structures in Oklahoma-Kansas zinc-lead mining field: American Association of Petroleum Geologists Bulletin, v. 17, no. 12, p. 1436-1445.

Germanov, A.I., 1961, Geochemical and hydrodynamic conditions of epigenetic uranium mineralization in petroleumwater zones: Geochemistry, no. 2, p. 107-120 (translated from Geokhimiya).

Glossary of Geology and Related Sciences, 1960, 2nd Ed.: American Geological Institute, Washington, D.C., p. 6.

Goldhaber, M.B., Reynolds, R.L., and Rye, R.O., 1979, Formation and resulfidization of a south Texas roll-type uranium deposit: U.S. Geological Survey Open-File Report 79-1651, $41 \mathrm{p}$.

Gornitz, Vivien, and Kerr, P.F., 1970, Uranium mineralization and alteration, Orphan Mine, Grand Canyon, Arizona: Economic Geology, v. 65, no. 7, p. 751-768.

Gott, G.B., Wolcott, D.E., and Bowles, C.G., 1974, Stratigraphy of the Inyan Kara Group and localization of uranium deposits, southern Black Hills, South Dakota and Wyoming: U.S. Geological Survey Professional Paper 763, 57 p.

Granger, H.C., 1968, Localization and control of uranium deposits in the southern San Juan Basin mineral belt, New Mexico-an hypothesis: U.S. Geological Survey Professional Paper 600-B, p. B60-B70.

Gruner, J.W., 1955, Concentration of uranium by carbon compounds: Economic Geology, v. 50, no. 5, p. 542-543.

Grutt, E.W., Jr., 1957, Environment of some Wyoming uranium deposits, in Advances in nuclear engineering: Nuclear Engineering and Science Congress, 2nd, Philadelphia, Proceedings 2nd Conference, v. 2, p. 313-323.

Hail, W.J., Jr., 1957, Reconnaissance for uranium in asphaltbearing rocks in the Western United States: U.S. Geological Survey Bulletin 1046-E, p. 55-85.

Hail, W.J., Jr., Myers, A.T., and Horr, C.A., 1956, Uranium in asphalt-bearing rocks of the Western United States, in Page, L.R., Stocking, H.E., and Smith, H.B., compilers, Contributions to the geology of uranium and thorium by the U.S. Geological Survey and the Atomic Energy Commission for the United Nations International Conference on Peaceful Uses of Atomic Energy, Geneva, Switzerland, 1955: U.S. Geological Survey Professional Paper 300, p. 521-526.

Haji-Vassiliou, Andreas, and Kerr, P.F., 1973, Analytic data on nature of urano-organic deposits: American Association of Petroleum Geologists Bulletin, v. 57, no. 7, p. 1291-1296.

Handford, C.R., and Granata, G.E., 1979, Uraniferous asphaltite in Moore and Potter Counties, Texas: U.S. Department of Energy Report no. GJBX-121(80), prepared for the Department by Bureau of Economic Geology, University of Texas at Austin, $20 \mathrm{p}$.
Harshman, E.N., 1961, Paleotopographic control of a uranium mineral belt, Shirley Basin, Wyoming: U.S. Geological Survey Professional Paper 424-C, p. C4-C6.

1972, Geology and uranium deposits, Shirley Basin area, Wyoming: U.S. Geological Survey Professional Paper 745, $82 \mathrm{p}$.

Hausen, D.M., 1959, Paragenesis of the Temple Mountain uraniferous asphaltites, Emery County, Utah: U.S. Atomic Energy Commission RME-101, issued by Technical Information Service, Oak Ridge, Tenn., 70 p.

Hawley, C.C., Wyant, D.G., and Brooks, D.B., 1965, Geology and uranium deposits of the Temple Mountain district, Emery County, Utah: U.S. Geological Survey Bulletin $1192,154 \mathrm{p}$.

Hess, F.L., 1922, Uranium-bearing asphaltic sediments of Utah: Engineering and Mining Journal Press, v. 114, no. 7, p. 272-276.

Hill, J.W., 1953, Regional reconnaissance for uranium and thorium in the United States, south-central district, in Search for and geology of radioactive deposits, Semiannual progress report, December 31, 1952 to May 31, 1953: U.S. Geological Survey TEI-330, issued by U.S. Atomic Energy Commission Technical Information Service, Oak Ridge, Tenn., p. 200-204.

1957, Uranium-bearing carbonaceous nodules of southwestern Oklahoma: Oklahoma Geological Survey Mineral Report 33, 6 p.

Hinckley, D.N., 1955, Reconnaissance of the Cameron area, Coconino County, Arizona: U.S. Atomic Energy Commission RME-81 (Revised), issued by Technical Information Service, Oak Ridge, Tenn., 21 p.

Hoekstra, H.R., and Fuchs, L.H., 1960, The origin of thucholite: Economic Geology, v. 55, no. 8, p. 1716-1738.

Hyden, H.J., 1961, Distribution of uranium and other metals in crude oils: U.S. Geological Survey Bulletin 1100-B, p. 17-97.

Jacobs, M.L., 1970, Elucidation of the organic matrix from a uranium ore: Fort Collins, Colo., Colorado State University $\mathrm{Ph}$. D. thesis, $156 \mathrm{p}$.

Kerr, P.F., and Kelley, D.R., 1956, Urano-organic ores of the San Rafael Swell area, Utah: Economic Geology, v. 51, no. 4, p. 386-391.

Keys, W.S., and White, R.L., 1956, Investigation of the Temple Mountain collapse and associated features, San Rafael Swell, Emery County, Utah, in Page, L.R., Stocking, H.E., and Smith, H.B., compilers, Contributions to the geology of uranium and thorium by the U.S. Geological Survey and Atomic Energy Commission for the United Nations International Conference on Peaceful Uses of Atomic Energy, Geneva, Switzerland, 1955: U.S. Geological Survey Professional Paper 300, p. 285-298.

King, J.W., 1956, Uranium deposits in the Black Hills: Mining Engineering, v. 8, no. 1, p. 41-46.

Klemic, Harry, and Baker, R.C., 1954, Occurrences of uranium in Carbon County, Pennsylvania: U.S. Geological Survey Circular 350, 8 p.

Langen, R.E., and Kidwell, A.L., 1974, Geology and geochemistry of the Highland uranium deposit, Converse County, Wyoming: Mountain Geologist, v. 11, no. 2, p. 85-93. 
Lekas, M.A., and Dahl, H.M., 1956, The geology and uranium deposits of the Lisbon Valley anticline, San Juan County, Utah, in Intermountain Association of Petroleum Geologists Guidebook 7th Annual Field Conference, Geology and economic deposits of east central Utah, 1956: p. 161-168.

Lewis, R.Q., Sr., and Campbell, R.H., 1965, Geology and uranium deposits of Elk Ridge and vicinity, San Juan County, Utah: U.S. Geological Survey Professional Paper 474-B, p. B1-B69.

Love, J.D., 1970, Cenozoic geology of the Granite Mountains area, central Wyoming: U.S. Geological Survey Professional Paper 495-C, 154 p.

Love, J.D., and Antweiler, J.C., 1973, Copper, silver, and zinc in the Nugget Sandstone, western Wyoming, in Wyoming Geological Association Guidebook 25th Annual Field Conference, Geology and mineral resources of the greater Green River Basin, 1973: p. 139-147.

Ludwig, K.R., Goldhaber, M.B., Reynolds, R.L., and Simmons, K.R., 1982, Uranium-lead isochron age and preliminary sulfur isotope systematics of the Felder uranium deposit, south Texas: Economic Geology, v. 77, no. 3, p. 557-563.

McCauley, J.F., 1957, Preliminary report on the sedimentary uranium occurrences in the state of Pennsylvania: Pennsylvania Geological Survey, 4th series, Progress Report 152, 22 p.

Mueller, Andreas, and Halbach, Peter, 1983, The Anderson mine (Arizona) - an early diagenetic uranium deposit in Miocene lake sediments: Economic Geology, v. 78, no. 2, p. 275-292.

Otton, J.K., 1977, Geology of uraniferous Tertiary rocks in the Artillery Peak-Date Creek basin, west-central Arizona, in Campbell, J.A., ed., Short papers of the U.S. Geological Survey Uranium-Thorium Symposium, 1977: U.S. Geological Survey Circular 753, p. 35-36.

Pierce, A.P., Gott, G.B., and Mytton, J.W., 1964, Uranium and helium in the Panhandle gas field, Texas, and adjacent areas, with contributions by Henry Faul, G.E. Manger, A.B. Tanner, A.S. Rogers, Rosemary Staatz, and Betty Skipp: U.S. Geological Survey Professional Paper 454-G, p. G1-G57.

Pierce, A.P., Mytton, J.W., and Barnett, P.R., 1958, Geochemistry of uranium in organic substances in petroliferous rocks, in United Nations, Survey of raw material resources: International Conference on Peaceful Uses of Atomic Energy, 2nd, Geneva, 1958, Proceedings, v. 2, p. 192-198.

Pierce, A.P., and Rosholt, J.N., Jr., 1961, Radiation damage and isotopic disequilibria in some uranium-bearing asphaltite nodules in back-reef dolomites, Carlsbad, New Mexico: U.S. Geological Survey Professional Paper 424-D, p. D320-D323.

Pipiringos, G.N., 1955, Tertiary rocks in the central part of the Great Divide Basin, Sweetwater County, Wyoming, in Wyoming Geological Association Guidebook 10th Annual Field Conference, 1955: p. 100-104.

Proctor, P.D., 1953, Geology of the Silver Reef (Harrisburg) mining district, Washington County, Utah: Utah Geological and Mineralogical Survey Bulletin 44, 169 p.
Reyner, M.L., 1950, Preliminary report on some uranium deposits along the west side of the San Rafael Swell, Emery County, Utah: U.S. Atomic Energy Commission RMO-673, issued by Technical Information Service, Oak Ridge, Tenn., 32 p.

Reynolds, R.L., and Goldhaber, M.B., 1978, Origin of a south Texas roll-type uranium deposit, I, Alteration of irontitanium oxide minerals: Economic Geology, v. 73, no. 8, p. 1677-1689.

Robinson, C.S., and Gott, G.B., 1958, Uranium deposits of the Black Hills, South Dakota and Wyoming, in Wyoming Geological Association Guidebook 13th Annual Field Conference, Powder River Basin, 1958: p. 241-244.

Russell, R.T., 1958, Relationship of uranium ore deposits to petroleum- and gas-bearing structures, in United Nations, Survey of raw material resources: International Conference on Peaceful Uses of Atomic Energy, 2nd, Geneva, 1958, Proceedings, v. 2, p. 358-366.

Sears, J.D., 1924, Geology and oil and gas prospects of part of Moffat County, Colorado, and southern Sweetwater County, Wyoming: U.S. Geological Survey Bulletin 751-G, p. 269-319.

Sharp, W.N., and Gibbons, A.B., 1964, Geology and uranium deposits of the southern part of the Powder River Basin, Wyoming: U.S. Geological Survey Bulletin 1147-D, p. D1-D60.

Sherborne, J.E., Jr., Buckovic, W.A., Dewitt, D.B., Hellinger, T.S., and Pavlak, S.J., 1979, Major uranium discovery in volcaniclastic sediments, Basin and Range province, Yavapai County, Arizona: American Association of Petroleum Geologists Bulletin, v. 63, no. 4, p. 621-646.

Sims, H.M., 1957, Phase Two-Study of the effects of crude oil constituents on the reduction and precipitation of uranium: U.S. Atomic Energy Commission RME-3149, issued by Technical Information Service, Oak Ridge, Tenn., $21 \mathrm{p}$.

Soister, P.E., 1968, Stratigraphy of the Wind River Formation in south-central Wind River Basin, Wyoming: U.S. Geological Survey Professional Paper 594-A, p. A1-A50.

Soulé, J.H., 1956, Reconnaissance of the "Red Bed" copper deposits in southeastern Colorado and New Mexico: U.S. Bureau of Mines Information Circular 7740, 74 p.

Spence, H.S., 1930, A remarkable occurrence of thucholite and oil in a pegmatite dyke, Parry Sound district, Ontario: American Mineralogist, v. 15, no. 11, p. 499-520.

Stephens, J.G., 1964, Geology and uranium deposits at Crooks Gap, Fremont County, Wyoming, with a section on Gravity and seismic studies in the Crooks Gap area, by D.L. Healey: U.S. Geological Survey Bulletin 1147-F, p. F1-F82.

Sverjensky, D.A., 1984, Oil field brines as ore-forming solutions: Economic Geology, v. 79, no. 1, p. 23-37.

Thaden, R.E., Trites, A.F., Jr., and Finnell, T.L., 1964, Geology and ore deposits of the White Canyon area, San Juan and Garfield Counties, Utah: U.S. Geological Survey Bulletin 1125, $166 \mathrm{p}$.

Turner, D.S., 1955, Selected oil and gas fields of northwestern Colorado and southwestern Wyoming, in Guidebook to the geology of northwest Colorado 6th Annual Field Conference: Intermountain Association of Petroleum Geologists and Rocky Mountain Association of Geologists, p. 119-122. 
Weeks, A.D., and Eargle, D.H., 1960, Uranium at Palangana salt dome, Duval County, Texas, in Geological Survey research 1960: U.S. Geological Survey Professional Paper 400-B, p. B48-B52.

Weeks, A.D., and Truesdell, A.H., 1958, Mineralogy and geochemistry of the uranium deposits of the Grants district, New Mexico, in Geologic investigations of radioactive deposits-Semiannual progress report, Dec. 1, 1957-May 31, 1958: U.S. Geological Survey TEI-740, issued by U.S. Atomic Energy Commission Technical Information Service, Oak Ridge, Tenn., p. 72-77.

Weir, D.B., 1952, Geologic guides to prospecting for carnotite deposits on Colorado Plateau: U.S. Geological Survey Bulletin 988-B, p. 15-27.

Witkind, I.J., and Thaden, R.E., 1963, Geology and uraniumvanadium deposits of the Monument Valley area, Apache and Navajo Counties, Arizona, with sections on Serpentine at Garnet Ridge, by H.E. Malde and R.E. Thaden, and Mineralogy and paragenesis of the ore deposit at the Monument No. 2 and Cato Sells mines, by D.H. Johnson: U.S. Geological Survey Bulletin 1103, 171 p.

Woodward, L.A., Kaufman, W.H., Schumacher, O.L., and Talbott, L.W., 1974, Strata-bound copper deposits in Triassic sandstone of Sierra Nacimiento, New Mexico: Economic Geology, v. 69, no. 1, p. 108-120.

Yellich, J.A., Cramer, R.T., and Kendall, R.G., 1978, Copper Mountain, Wyoming, uranium deposit-rediscovered, in Wyoming Geological Association Guidebook 30th Annual Field Conference, Resources of the Wind River Basin, 1978: p. 311-327.

Zitting, R.T., Masters, J.A., Groth, F.A., and Webb, M.D., 1957, Geology of the Ambrosia Lake area uranium deposits, McKinley County, New Mexico: Mines Magazine, v. 47 , no. 3 , p. 53-58. 
4 
